\title{
On the Memory of Ice: An Interview with Jonathan Marquis by Kathy Kasic
}

\author{
Kathy Kasic ${ }^{a}$ \\ Keywords: glaciers, climate change, site-specific artwork, embodiment, cyanotypes, photography, landscape \\ https://doi.org/10.1525/001c.13462
}

\begin{abstract}
When I discovered Jonathan Marquis's cameraless photographic work, I found myself entranced. As a filmmaker primarily focused on environmental documentary narratives, I often record digital images of a world I fear we are losing. Perhaps especially because camera electronics transform light and dark shapes into digital pixels, I try to make my images as tactile and sensory as possible so that we may become within a place. Jonathan Marquis's cyanotype series, Downwaste, created in Glacier National Park, raises questions about photography, time, place, and agency as the climate changes and the glaciers melt. I had the good fortune to spend some time interviewing him about his work. What follows is our discussion.
\end{abstract}

Kathy Kasic: Jonathan, I thoroughly enjoyed looking at your photographic series and thinking about your process of making it. It's insightful, abstract, and sublime. So many different adjectives come to mind.

Jonathan Marquis: Thank you, Kathy, it is a pleasure to join you. We're talking about Downwaste, a series of cyanotype photographs made at and with the melting edge of glaciers in Glacier National Park. Downwasting is the term in glaciology that refers to the thinning of a glacier due to melting ice. I use the term, first of all, because it refers to the site of the artwork's production as well as to the losses in these places due to anthropogenic climate change. I hope the project invites viewers to think with glaciers as meaningful actors whose presence shapes the physical and psychological landscapes that humans and glaciers co-inhabit.

KK: It has been reported, by the US Geological Survey and subsequently the New York Times, among other sources, that Glacier National Park is losing its glaciers at an unprecedented rate as a result of climate change. Did this shrinking and disappearance of glaciers motivate you to work on this project?

JM: Yes, it did. When I first started working with this subject in 2014, I was seeing mostly repeat photography that tracked glacial retreat, and I felt that this heavy emphasis on loss obscured some of the active, complex, and overlapping realities of humans and ice on the ground. In conceiving of Downwaste, I

\footnotetext{
a Kathy Kasic is a documentary filmmaker and an assistant professor at California State University, Sacramento. Kasic began her career as an evolutionary biologist in the Ecuadorian Amazon searching out a small nocturnal frog; but for the last sixteen years, she has been a director and cinematographer of over one hundred documentaries and lyrical films. Her awardwinning work has screened at international festivals and museums and has been broadcast on television, with outlets including BBC, Discovery, Smithsonian, PBS, and National Geographic. Her films seek to unveil the human relationship with the natural world through a sensorial emphasis on place. Kasic's most recent documentary work, 3600 Feet Beneath the /ce, tells the story of an international team of scientists, known as SALSA, who explore a subglacial lake buried 3,600 feet beneath the West Antarctic Ice Sheet to better understand our rapidly changing climate. You can follow SALSA's research on social media under @salsaantarctica or visit kathykasic.com for a selection of her films.
} 


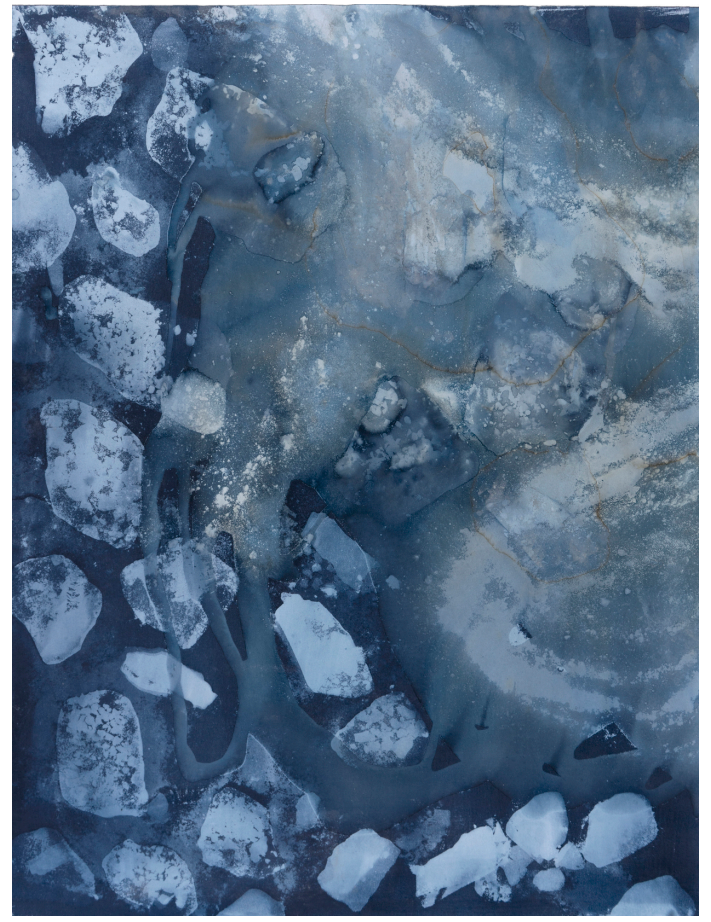

Figure 1: Downwaste (Siyeh I), 2017. Cyanotype on paper, 30" x 22".

Courtesy of Jonathan Marquis. Downwaste gallery available at: http://www.jonathanmarquis.com/downwaste

wanted to put myself at the source of the trouble to create artworks that are not only about global issues of climate disaster and melting glaciers, but also about a specific place that I live and dwell in.

KK: What previous work led you to create the Downwaste series?

JM: In 2014 I was working on the Glacier Drawing Project-a long-term endeavor to draw every remaining glacier in the state of Montana.

KK: Were you successful in doing that? Were you able to draw every glacier in Montana?

JM: I'm actually getting really close! It's an ongoing project, and I've drawn the majority of the glaciers (for an example, see figure 2). At this point, the ones that I have left are pretty isolated and challenging to get to, but each summer I visit a handful more, and I hope that by summer of 2020 or 2021, I'll have been to every named glacier in Montana.

Downwaste really came out of those experiences of drawing, where I noticed something forming between myself and the glacier. I started wondering: who is drawing who here? I could see that what ice and snow did to rock-carve it, mark it, transform it - was not all that different from what I was doing on the paper with rock in the form of a pencil. I started to explore the question, does a glacier draw? And I started to reflect on the role of artwork and imagery in communicating these places and the cultural ideas that are rooted in colonial ways of thinking and viewing. I could no longer keep seeing a glacier as an 


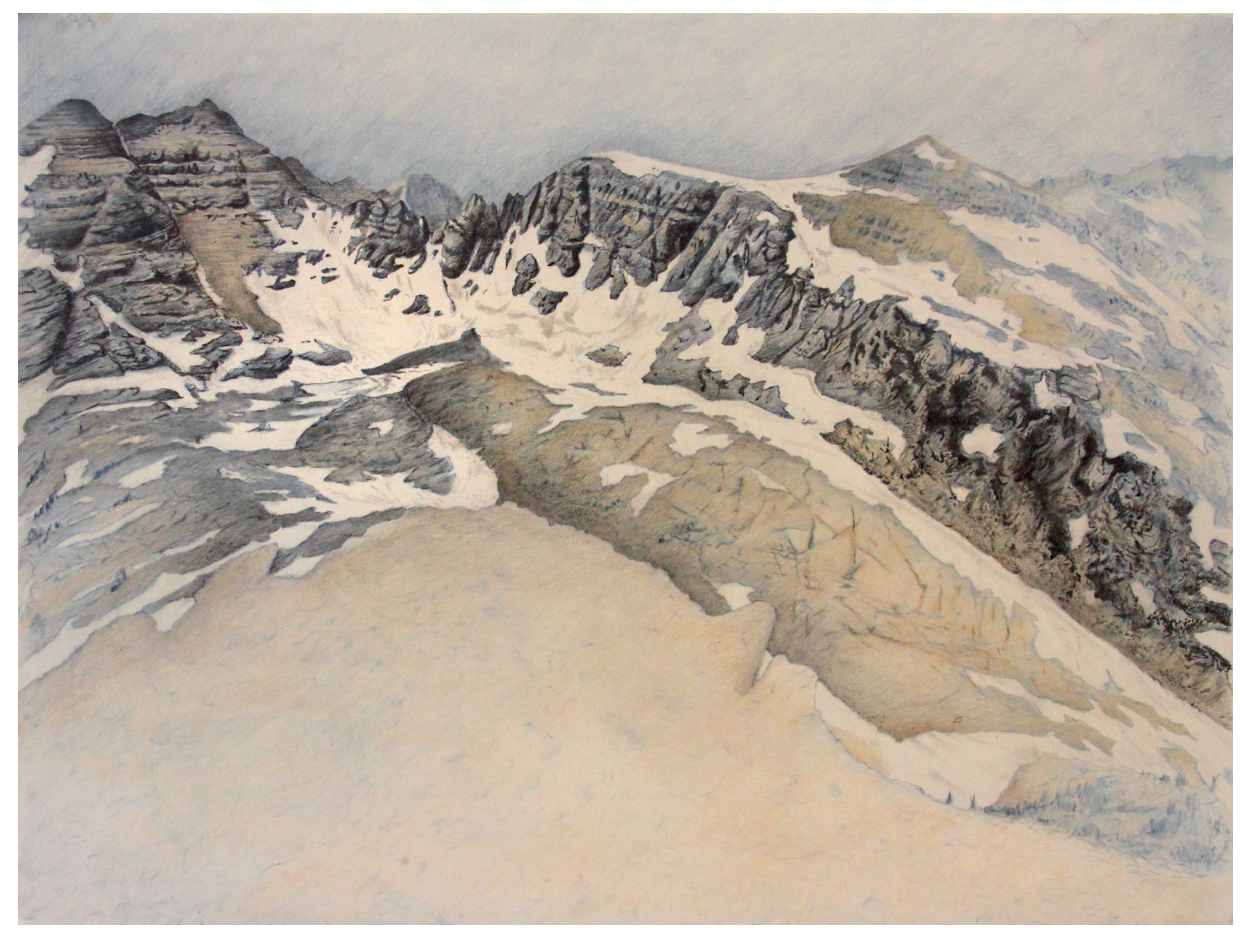

Figure 2: Fissure Glacier - Mission Mountain Wilderness, MT from the Glacier Drawing Project, 2015. Graphite and color pencil on paper, 18 " x 24".

Courtesy of Jonathan Marquis. Downwaste gallery available at: http://www.jonathanmarquis.com/downwaste

object out there that I was subjecting to my particular hand and gaze. Instead, I started seeing that the glacier and I were caught up in a mutually co-generated, sensory encounter.

At about this time, I think it was 2016, I learned about this medium of cyanotype, which is responsive to light and material encounters. I heard a talk by the photo historian and writer Geoffrey Batchen about his book Emanations: The Art of the Cameraless Photograph (2016), and I became interested in the ways cameraless photography collapses the distance between the actual object and a representation of that object. This propelled me to study and then to experiment with cyanotypes. Anna Atkins is often considered the first person to create a photo book with the cyanotype medium. She was also a botanist, and the books were beautiful taxonomic explorations of plants. I like this overlap that cyanotype has with science and art.

So I made some initial experiments with small rocks that resembled large mountains to get at the fractal nature of geology and problematize scales of viewing. I also did some in collaboration with a photographer on the coast of California. The cyanotype medium allowed me to envision other ways to think with glaciers and embed myself in geologic time.

KK: So you're referring to an embodied way of taking a photograph without a camera? Your drawings are more representational, but these other works are completely abstract. It's an interesting mix to have these two bodies of work. 
It's almost like you're feeling too remote when you're drawing them, so you end up having to become part of them, which is what the cyanotypes seem to do.

JM: The idea of becoming with glaciers, and landscapes generally, underlines my approach to the work. The cameraless photographic medium in a sense collapses or focuses the scale of the geologic into these little moments of abstraction on paper. And it dawned on me that the glacier quite literally draws itself. When I worked on the drawings, it really felt like the glaciers were writing or drawing my life as much as I was drawing them, so it made sense to move toward a medium that made this experience more explicit.

KK: That's really beautiful. So you started doing the cyanotypes in California. What were your subjects there?

JM: In California, I worked on a collaborative project with photographer Tomiko Jones called Waterlines (2017). We were traveling around California right after a several-years drought and a winter with some of the heaviest snows and rains in decades. The water brought relief, but it also threatened to damage reservoirs, causing massive flooding. We were interested in this relationship between water and society, extreme weather, the journey of water from the mountains to the ocean, and thinking about how dependent we are from it falling or not falling. The project was a response to the urgencies of water and the rapid fluctuations from scarcity to abundance in a time of extreme weather and climate change. Tomiko made photos with a $4 \times 5$ film camera of various natural and human-made water features. We exposed the negatives using cyanotype onto a piece of paper, and then applied a second layer of cyanotype solution, and took them down to the ocean to develop into abstract images using the materials of the sea. Those moments of material encounter with the ocean gave me the idea to take this approach to the glaciers in Montana.

$\mathrm{KK}$ : Kind of like going to the source of that river water?

JM: Yes, the source! In fact, the locations we chose for the collaborative works followed the winter floods from mountain to reservoir, to river, and finally, to sea.

KK: I've never done the cyanotype process before, but after looking at your work, I really want to try it.

JM: You visit Montana, right? Let's go out this summer, and we'll do some.

KK: Oh, that would be great! I'd love to. I do go to Montana-well, I used to live there for fifteen years. 
JM: That's wonderful. I'm glad we share that connection. Making cyanotypes on the land is an interesting opportunity to just be out and talk with people. Maybe there is even a collaboration we could come up with that can utilize both of our skills. We can talk about that later.

KK: That could be really interesting. I do want to talk about this process more. I'm interested in what it uses. I understand that the chemicals involved are nontoxic, right?

JM: You don't want to drink it, but yes, it's nontoxic. It ultimately becomes iron when it exposes, so it's kind of like a mineral.

KK: So it's made of ferric ammonium citrate and potassium ferricyanide? That's what I've found.

JM: That's right, that's the chemistry.

KK: And do you use any kind of special paper, or does that come pretreated?

JM: You can purchase it pretreated from various suppliers, but because of the scale I'm working with, I treat all of my own paper.

KK: Do you get more control if you do that?

JM: I definitely get more control over the size and composition. I like to apply the solution to high-quality cotton-based drawing paper. It has more weight to it and is rigid enough to hold up when I'm out in the field placing ice and rocks on it.

KK: Can you explain that process a little bit more?

JM: Sure, I'll start from the beginning. The night before I go out, I'll coat the paper with the cyanotype solution. I'll usually treat about a dozen eight-byten images and half a dozen twenty-two-by-thirty-inch images. I treat them at night because once the chemicals are applied to the paper, it becomes sensitive to light. I then package everything into lightproof containers for the walk to the glacier. Usually, I am hard-pressed to make it to a glacier without hiking at least seven to eight miles one way. So I get up early, hike out, and try to be on-site by the middle part of the day when the sun is highest. I am totally dependent on direct sunlight for a good exposure, so I cross my fingers for a cloud-free day, which almost never happens in Glacier National Park. Wind, which is usually in abundance, can make things tricky too when you're working with paper. I then seek out a spot near the glacier with a good place to work and where it has the various elements that I'm looking for-ice, meltwater, rocks, silt, debris. Once I find the site, I use the smaller pieces of paper to do some tests to warm up and get a sense of how things will work that day. Then I move on to the larger ones. Usually, I'll let the glacial meltwater run on the cyanotype first because that will create fluidity and layered effects in the final image. Sometimes I will briefly press the paper right onto the ice to add some texture. Then I 
quickly place ice, glacier rocks, debris, and silts on the surface and allow it to expose in the sun for approximately nine to twelve minutes. In the last one to two minutes of the exposure, I'll change some things around to complicate the layers. So the end result looks more like the layers of ice and debris in a glacier. Once that part of the exposure is done, I'll remove all of the ice and rocks, maybe give it a brief rinse, and let it dry for a little bit, so I can take it back into town for the final rinse and complete the exposure.

KK: So then you wash it off with water? Does this mean that you don't see the image until you get home?

JM: Yes, and yes, but let me back up for just a second and describe how the exposure works. The UV rays from the sun chemically transform the solution on the paper into an iron compound. When that is submerged in water, another reaction turns it blue. Depending on how much sun hits an area, you get different values of blue; more sun creates a darker blue, and less sun produces lighter shades. Where no UV light reaches the surface, the solution washes off in the final bath, and these areas remain the same color as the surface of the paper; in my case, white. I avoid doing the final rinse out in the field, even though those chemicals are not very toxic and more or less minerals. I want to minimize their introduction into the wildlands as much as possible to respect the integrity of these places. So I usually don't do the final rinse until I return home. After the final bath, it takes the cyanotype about twentyfour hours to reach its final appearance, unless one adds hydrogen peroxide to the water, which makes the transformation instantaneous-a little trick of the trade. But out in the field, I don't use hydrogen peroxide, so even though I can see the process at work, I do not see the final result until much later. During the process, at the glacier, the images are all green, orange, and wild, but most of all this turns blue in the end.

KK: I'm looking at your imagery now and thinking about how you must have done that in each one. In the piece entitled Downwaste (Siyeh I) (figure 1), it looks like you must have placed some smaller rocks. Is that what happened there?

JM: Yes, on the right side of the image, you can see where at the start, I dipped the paper in glacial runoff. Then I placed rocks on the paper. Inside those rocks, you can see smaller rocks and silt textures. I create those areas during the last minute or two of the exposure by removing the larger rocks and tossing pebbles and silts in those areas to create another layer of exposure. All these actions were made spontaneously and quickly out in the field, because once the lightsensitive paper is removed from the lightproof container [and put] into the bright alpine sun, it begins to expose immediately. There is very little time to plan and make choices, so you just have to act on the fly. These ten-minute light paintings are like on-the-spot performative happenings. 


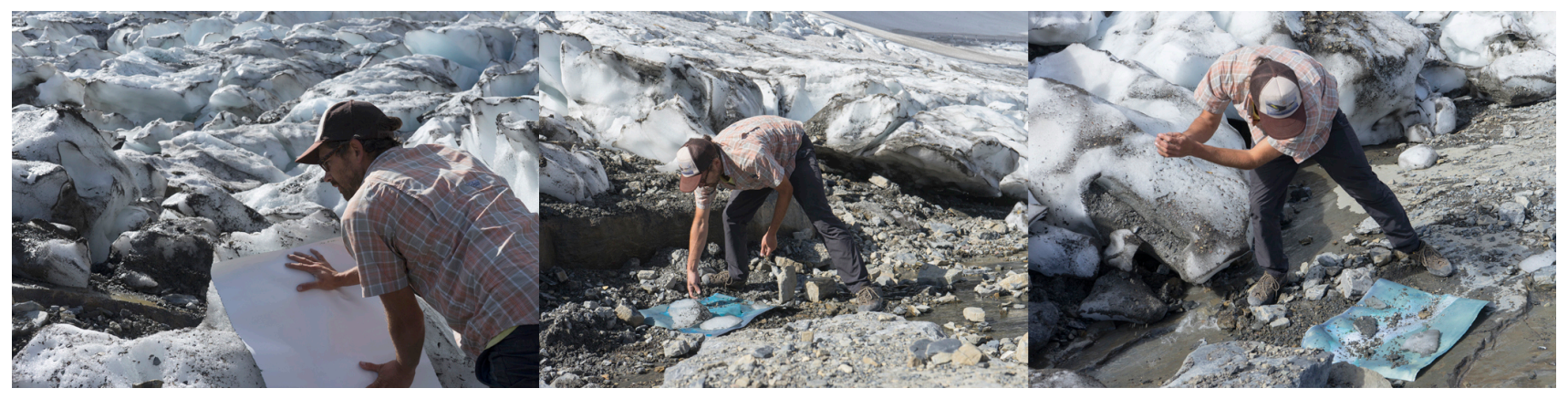

Figure 3: Jonathan Marquis in the field, making a cyanotype for Downwaste, 2019.

Courtesy of Jonathan Marquis. Downwaste gallery available at: http://www.jonathanmarquis.com/downwaste

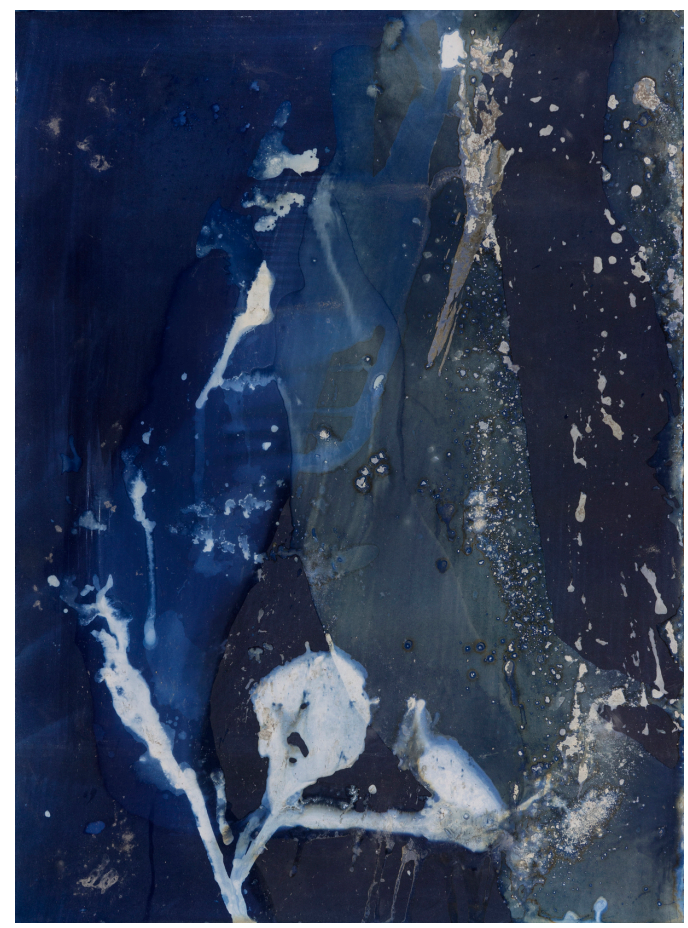

Figure 4: Downwaste (Grinnell II), 2019. Cyanotype on paper 30" x 22".

Courtesy of Jonathan Marquis. Downwaste gallery available at: http://www.jonathanmarquis.com/downwaste

KK: The one called Downwaste (Grinnell II) (figure 4) almost has something very plantlike or like a seedling down at the bottom. However, this doesn't seem to be a plant. What did you do there?

JM: Ah, the one with a stem with three little nodes on it? The more linear aspects were probably from water that rinsed the solution completely off before it could expose. I think some of the more bulblike parts might have been from rocks or chunks of ice sitting on the surface. It's hard to say exactly because everything is happening rapidly on-site and, as I mentioned, I don't really see the final image until later. Ultimately, though, the combination of material and abstract processes allows us to see any form we want! 


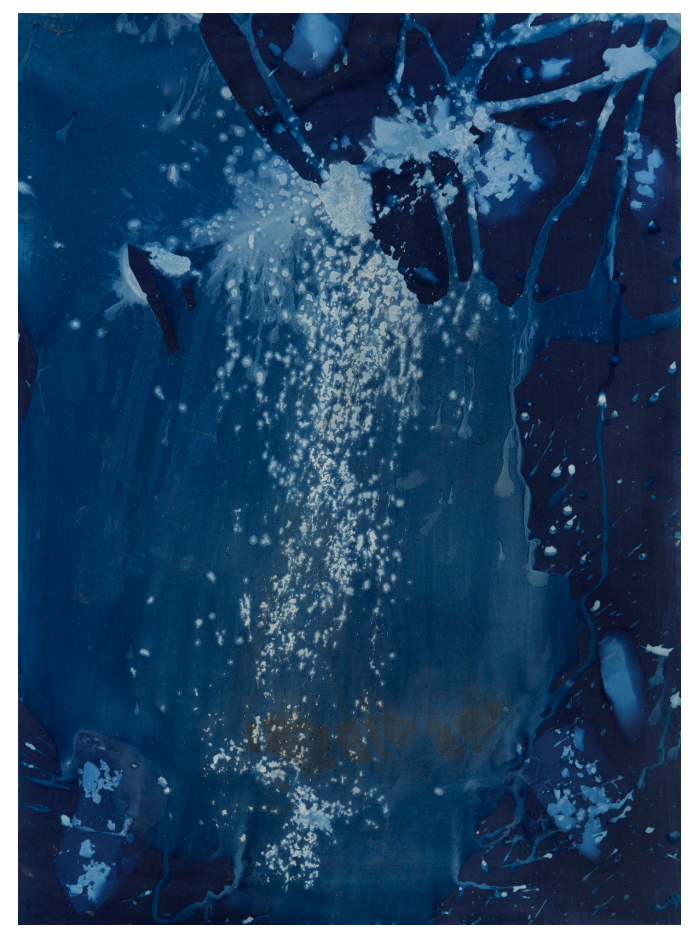

Figure 5: Downwaste (Sperry I), 2019. Cyanotype on paper 30" x 22".

Courtesy of Jonathan Marquis. Downwaste gallery available at: http://www.jonathanmarquis.com/downwaste

I don't intend to produce representational images even though sometimes something like that might emerge. There is one that even looks like it has a face in it, but I resist seeing abstraction as a Rorschach image. It's really the outcome of material encounters and processes.

KK: Yes, it's really about a feeling you get when you look at some of these images. I was struck by the different emotions that I get from each of them. I know we're not thinking about it in a representational way, but Sperry I (figure 5), for example, does look like the droplets are falling in a way that's much more stochastic than the others previously, like Siyeh I or Grinnell II. Siyeh I looks so peaceful and serene, everything feels frozen, while Grinnell II seems to be a mix of melting rivulets. Sperry $I$ and $I I$ feel more explosive. Can you explain how they took on these kinds of forms?

JM: That one (figure 5) is from Sperry Glacier, which is one of the primary glaciers that the USGS and climate scientists study and use to set a standard to understand how other glaciers are melting in Glacier National Park. There are also really significant historical images of it that show how much it has melted and changed over the years.

So how did Sperry I take on a more ethereal, melted character, whereas the other ones didn't? Your guess is probably as good as mine! I usually have an idea or feeling of what I want the composition to look like, and then that usually falls apart pretty quick. In the larger open mass that begins on the left in Sperry $I$, I was probably trying to get a small dip into the runoff to get little flowy 


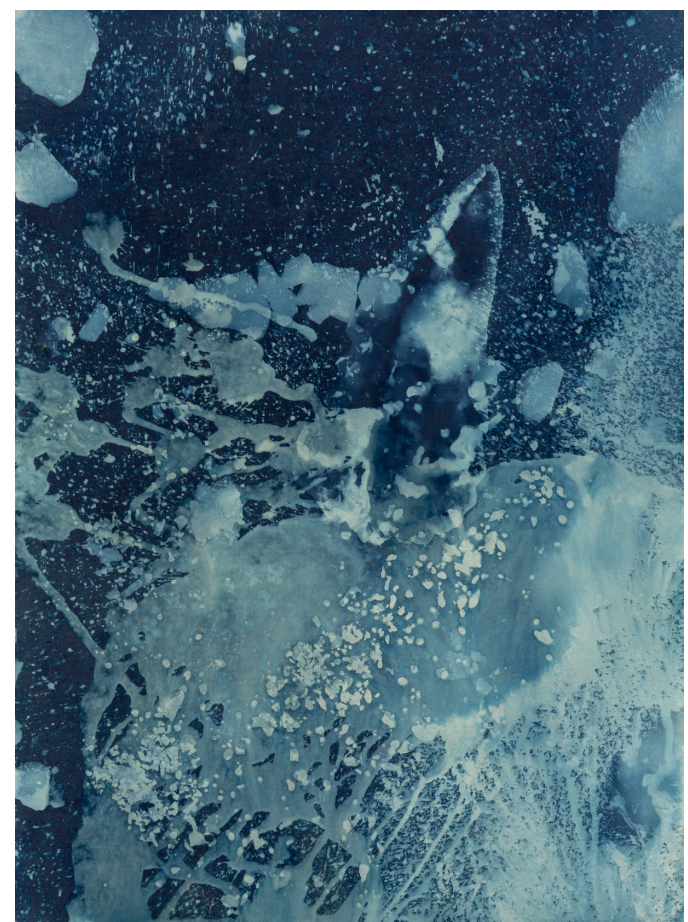

Figure 6: Downwaste (Sperry II), 2019. Cyanotype on paper 30" x 22".

Courtesy of Jonathan Marquis. Downwaste gallery available at: http://www.jonathanmarquis.com/downwaste

linear elements, and then the water totally grabs the paper, and next thing you know, half of the paper is covered in water, and it's flowing all over the place. So I'm forced to respond and act quickly. Now, does it look the way it does because of the specifics of that glacier and place? Or does it have to do with me and how I approach it that day? How inspired or tired I am? Is it just a bad dip into the water? I'm not sure, but it does seem that the conditions at each site, personal and glacial, produce a consistency across the works made at that spot. It's hard to explain why that is. There is a magic and chance, and in the moment, there is little clear knowledge of what the final product is going to be.

KK: I can see that, but at the same time, it does look like you have some sort of knowledge. I mean with Sperry II (figure 6), you seem to be going for something rather explosive. There is more action somehow here; it looks like it's been splashed, almost.

JM: The explosive aspects are a result of the gestures, the way that I tossed and threw rock and silt on it. Since I'm working under the pressure of time, I have to work really quickly, and I'm tossing and throwing things like an abstract expressionist or something. I'm pretty exhausted by the end of it. There is a timing structure I work with, and that produces some consistency, and I have a general idea at the start of each piece, but the way that takes place is very rapid, very spontaneous, very quick and subject to change. Sometimes I get something like the results I want, most times I don't, and the glacier gets the final say. I think a lot of what you're picking up on has to do with how many of the rocks are exposed. Siyeh I has a lot of rocks that physically ground it, 
whereas in some other ones, the rocks get totally blown out by the water or disappear through the process. I've been surprised how each glacier allows the work to have its own kind of feel and character.

$\mathrm{KK}:$ Then it really is the characteristics of the glacier?

JM: Yes, what is available on-site determines the outcome. I think of the work as a collaboration with the glacier. The land shapes my body and my response. Is it steep? Is it flat? Is it rocky? Is it loose and more unstructured? A lot of these areas have just been recently exposed from the ice and are very unstable. At one of the first glaciers I did the process sent frequent rocks sliding down toward me as the sun loosened their grip on the ice. Most of them were small, but an occasional basketball-size rock came hurling down, and I had to run out of the way. These factors will totally determine the shapes, the gestures, and where I can put the cyanotypes. Some days I'll get rained out, so my art, like a baseball game, is weather dependent. It's all quite fascinating. How close am I to the glacier? Can I reach out and touch it, or am I somewhere else? This also marks the difference with, for example, the one at Siyeh versus the one at Sperry. Siyeh is predominantly a rock glacier now, which means that the ice is underground in the rocks. Actually, in the area where I worked, there was not any snow or ice around to use, since it was all buried below.

KK: That's amazing. In Siyeh I (see figure 1), the one that I would say looks the most like ice, you're saying that that's the one that had the least ice. Then what we almost have here is a memory of its ice.

JM: That is such a poetic way to put it.

$\mathrm{KK}$ : So there are some challenges with this process when there are materials you can't get to.

JM: Yes, each place and their materials and processes determine the outcome. The very first grouping I ever did was at Siyeh Glacier. I was interested in Siyeh because in 2017 scientists had recently returned the glacier to active status. Previous estimates about the glacier's size were determined by aerial photography and satellite imagery, and it fell below the twenty-five-acre threshold that marks a glacier as active or not. However, subsequent field research discovered a lot more ice under the rocks, and Siyeh was reclassified as an active glacier once again. I was interested in this communication about how we understand what is or isn't a glacier-how remote satellite imagery may tell us one thing, but on the ground, we might have an entirely different experience. This seemed to get at some of the tensions between science and art, how they each communicate things differently. I was curious how we assign value and meaning to glaciers and come to understand these places in a time of planetary change.

KK: That's really interesting. I think you're catching on to some nuances that you can't really get in the same way with, for example, your drawings. 
Categorically speaking, there are so many different kinds of glaciers. What kinds are these?

JM: In Montana, they're all pretty much alpine glaciers of sorts. They're all relatively small glaciers compared to glaciers, say, in Alaska or Greenland.

KK: Do you think that the cyanotypes reflect the kinds of glaciers these are?

JM: Clearly, scientific language and categories are good for having critical discussions and understanding what happens in these places, so we can make informed decisions. But, for me, when I'm out there, those are the last things that I'm really thinking about. It's more of a sensory experience of being in a place, feeling one's body on the ground. I think that's what art as an activity, as a process, as a practice is really good at. Art, however, could never replace science or vice versa. Data and scientific terminology don't tell us what it's like on the ground in our bodies to stand in the presence of ice, totally exhausted and exhilarated. Data tells us that glaciers are melting and will disappear soon, but it doesn't tell us how to live with the melting glaciers that are still here, in the present. How do we think about and imagine them? I believe how we imagine a glacier or glacial systems has real effects on the ground. I think this tension is why I was initially drawn to Siyeh Glacier.

KK: Right, it's not as if the Siyeh suddenly becomes irrelevant because it's not twenty-five acres.

JM: Exactly. And who gets to make the choice when it's relevant again? To me, these are essential places that have been here forever as far as humans are concerned, and that's why I think they're worth saving, worth doing things about, worth talking about, clearly worth doing art and science about.

KK: I started as an artist, then became a scientist, and then a filmmaker. I often think that when I transitioned from being a scientist to being a filmmaker, I had to let go of details-those kinds of terms and things. The value we discover through art is of its sensorial capacity, our affective response to the way it can embody a place, and through this, it pushes us to think in a new light. I think these images do that. They are very haptic, you feel like you can touch them-like you're really part of them, becoming glacier. When they are explosive, you get this feeling like, it's all blowing up right in front of us- which has a correlation to that disaster of the actual melting of glaciers. That's my impression of your work.

JM: I appreciate your comment about their immediacy and haptic quality. What originally drove my interest in these places was the sensorial activity, enjoyment, and struggle of being out in these dramatic alpine places with ragged rocks, lakes-just really beautiful places to be. I was always trying to figure out how to communicate this sensorial aspect of the place. I really think of these works as a residue of the sensorial encounter between my body and the 


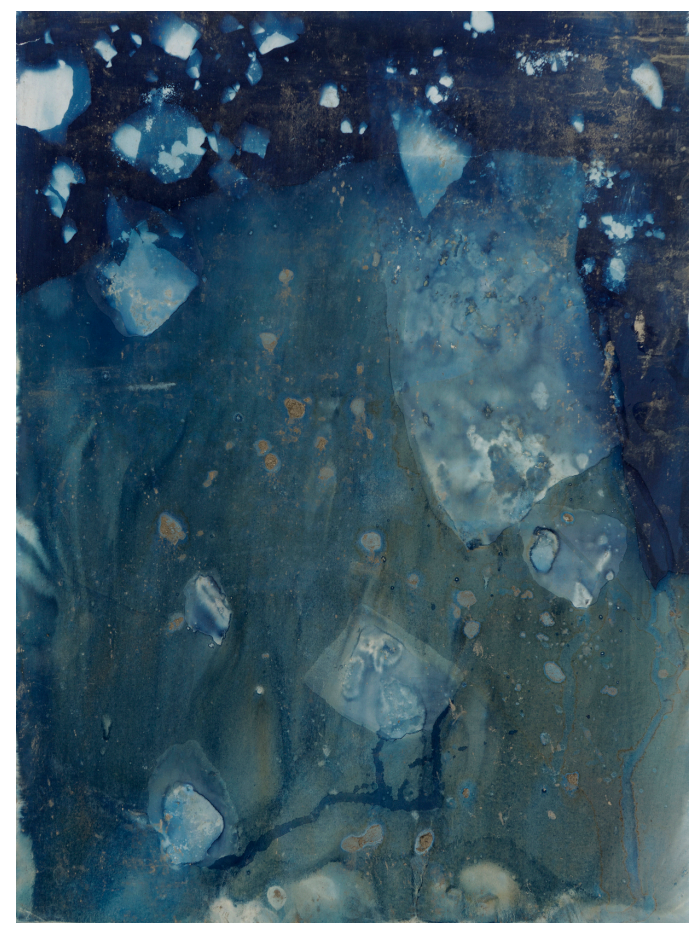

Figure 7: Downwaste (Swiftcurrent II), 2019. Cyanotype on paper 30" x 22".

Courtesy of Jonathan Marquis. Downwaste gallery available at: http://www.jonathanmarquis.com/downwaste

glacier's. I think this physical connection is what motivates somebody to try to assuage this disaster, and I think this is why some scientists describe the need for more emotional relevance to climate change data.

KK: I'm going to return to your imagery again. How did you decide what would be the top and what would be the bottom? There is a structure to your imagery, and I wonder about your storytelling. I think you may have been saying that you weren't telling a story, but it seems like when you pick a top and a bottom, you create structure, the backbone of a story. Or maybe there isn't a top and a bottom?

JM: There is certainly a narrative that these works filter and fit in with. That narrative is one of climate change and one of disaster, but the question of which way is up and which way is down is determined by gravity-which way the ice or water is flowing. I want to have something that feels like it's pulling us, with the title being Downwaste. Gravity is also crucial in the sense of groundedness and feeling connected with the land. Gravity is what is making all of this happen, it is pulling the glacier down the mountain and over the cyanotypes. On occasion when looking at them later in my art studio, I have switched the orientation around on some because I thought the composition was more successful and resolved.

KK: A story can also be told with what you've decided to get rid of. What did you get rid of? What did you keep and why? 
JM: I suppose the first thing I got rid of in Downwaste was any explicitly recognizable imagery or views. Also, a lot of what I produce on-site doesn't really turn out, it's just kind of chaos with splattered water all over the place. Some of these I keep, because I'm interested in all the chaotic instances too, but some just get too blown out.

KK: With the narrative of Downwaste being this idea of climate change, some people might pessimistically think that we've lost all the glaciers, even though some are still here today. Can you explain this kind of thinking?

JM: During the summer, to help me fund my projects, I do some local art fairs and markets. When I tell people I'm trying to draw every glacier in Montana, the most common response is "Well, you better hurry up!" They are sort of riffing and joking, but underlying this immediate reaction to my art is this bias or assumption that all of the glaciers are already gone or are going to be totally gone very soon. One of the scholars I've come across, M Jackson, describes this as a glacier ruin narrative that overlooks actual glaciers and rather speaks to an imagined state of loss that projects a predetermined glacierless future onto the present. As we were saying before, this loss narrative is problematic for lots of reasons. For one, it often deflects any responsibility for the disaster in the present, and there is less pressure to change our behavior because worldwide glacial disappearance is already a foregone conclusion. I feel it's important to know that glaciers are still here-lots of them, actually-and that we can and need to consider them and act now, not just for their sake but for all the critters, including humans, now and in the future, who depend on the ice and water.

KK: That's interesting. With your project, it seems more like a present moment rather than looking back to the past, having nostalgia for something that is gone. Would you say that's true?

JM: Right. I attempt to make this disaster immediate and present, not only through the theme of the work but also by embedding the artmaking in the present moment at actual glaciers. These are active processes that glaciers do day in and day out regardless of whether they are shrinking or growing in the larger climatic sense.

When I was drawing glaciers, I kept coming up with the idea of bringing the glacier into my belly. I did a series of videos called Ablation Sites. Ablation is a medical and geological term. In surgeries, ablation is the removal of body tissue to improve some health aspect or remove something damaging. Ablation on a glacier is the varying processes that cause ice to disappear. I really liked this dual meaning and the idea of the geologic becoming biologic. Where and when do our individual senses, our bodies, become instances of the geologic?

KK: How does that perspective help us? 
JM: That's a great question. To me, it's about getting in touch with the physicality of the world around us rather than experiencing only abstract data or a picturesque viewpoint that looks out from afar, or from a nowhere place. I think it helps us generate more curiosity and empathy. But I don't know, maybe Downwaste is just more disaster tourism? However, it's my hope that when these works go on display, they reroute some of the colonial gaze that sees the landscapes only as a picturesque viewpoint or relic of a pristine past, and instead help reframe glaciers, these more-than-human lives, as active, dynamic processes that we can have empathy and feel for right now. Hopefully, the term downwaste and the explosiveness of some of these works evoke and emphasize the serious consequences of this disaster.

One of the critiques that I myself have about this project is that it doesn't attend to the losses of the communities, like the Blackfeet Nation or local ranchers who live near and depend on the water from these glaciers. I'm trying to seek out new ways to address those issues. I don't think this is something that a particular image from Downwaste can resolve, but I'm hoping that by building relationships and creating dialogue through exhibitions, we can start to get at more of the historical, social losses and challenges of climate change.

$\mathrm{KK}$ : The artistic process is always a process of evolution.

JM: Indeed, it is. I think there is a value in art's ability to instigate discussions.

KK: Last year, I went to Antarctica and filmed a research expedition to access a subglacial lake that sits about 3,600 feet below the West Antarctic Ice Sheet-definitely bigger than 25 acres. We were there partially to understand past and present-day climate change and also to understand the evolution of life in extreme environments.

The bacterial life in the lake likely hasn't seen the sun since that area was an ocean. And since it never sees the sun, that bacterial life relies on broken-down pieces of rock to eat.

So, when I was thinking about your work, I was thinking about that aspect of the glacier itself and the cyanotype process. Maybe in those ways, you can draw comparisons between slow glacial changes as compared to the rapid chemical changes on the photographic paper, which are more anthropogenic, if you will. Have you thought of the contrast between these two different kinds of chemical changes?

JM: I really like that perspective. This idea of the slow time of geology and the rapid time of chemicals sparks me to wonder, is time chemical? In a way, these rapid, ten-minute exposures compress all this immense geologic time into a mere instant and disrupt any sense of time as being structured by the human experience. Perhaps looking at a glacier or these cyanotypes leads us to picture 


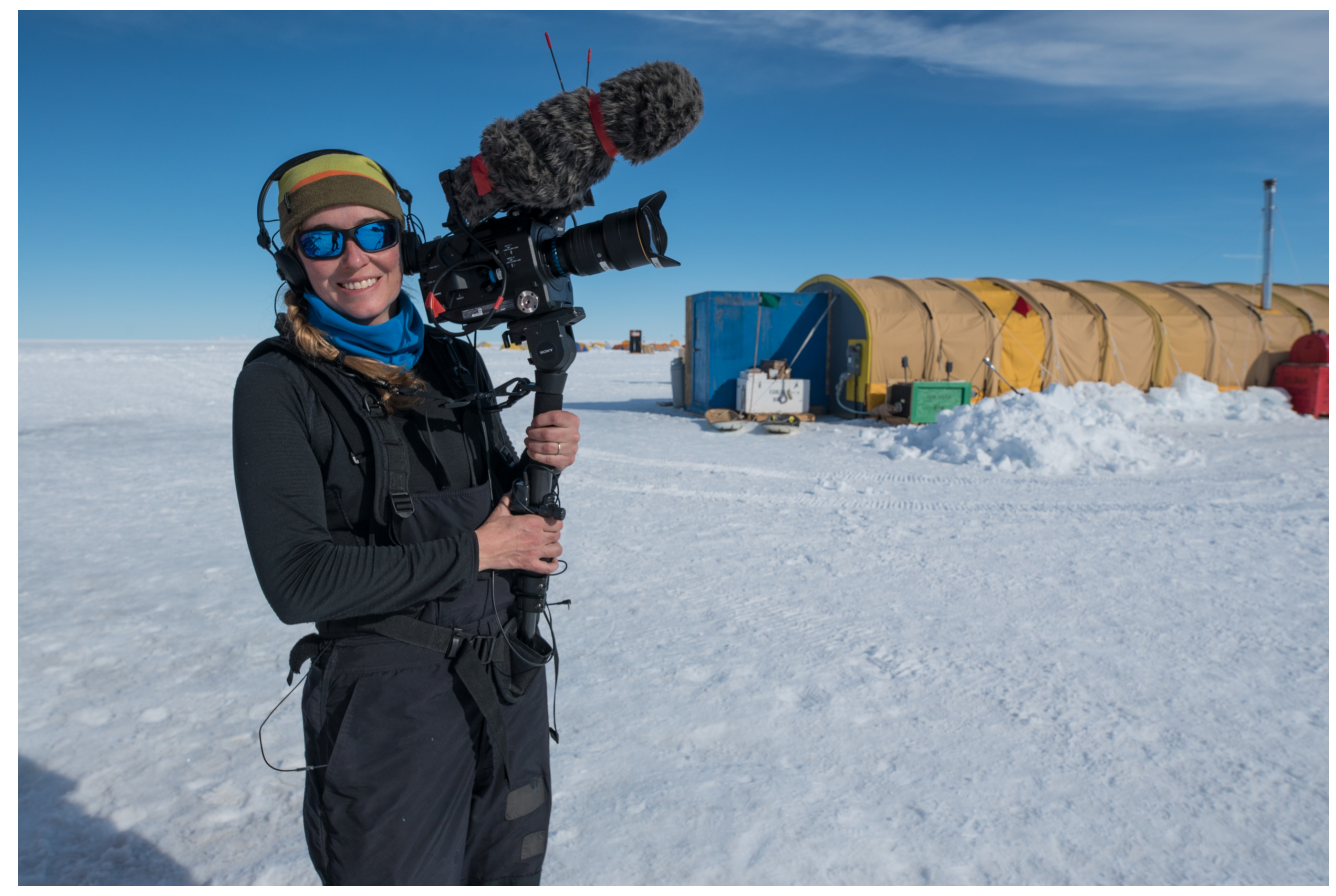

Figure 8: Kasic in Antarctica, on top of Subglacial Lake Mercer, 2019.

Courtesy of Kathy Kastic and the SALSA Science Team.

Figure 9: Video thumbnail, 3600 Feet Beneath the Ice - film trailer (4m 40s), 2020.

Courtesy of Kathy Kasic and the SALSA Science Team. Trailer available at: https://vimeo.com/349366131

ourselves in that vast sea of time. Yet glaciers can do things quite rapidly too, in sudden surges. Large sheets in Antarctica can break off in huge chunks in a matter of moments. 


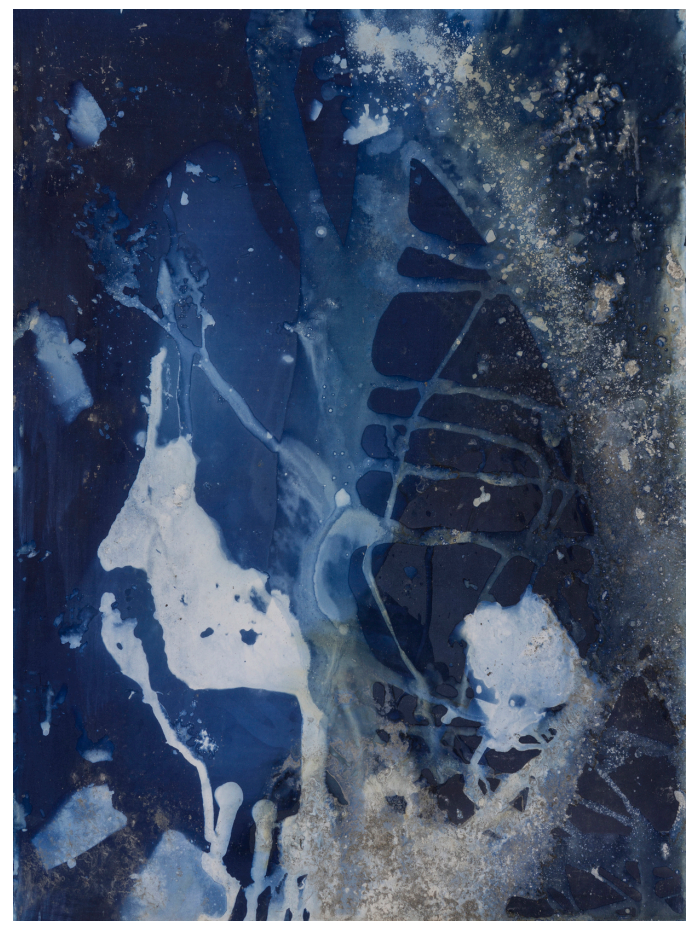

Figure 10: Downwaste (Grinnell I), 2019. Cyanotype on paper 30"x22".

Courtesy of Jonathan Marquis. Downwaste gallery available at: http://www.jonathanmarquis.com/downwaste

KK: Yes, time does seem to be a central element to all of this. Obviously, with climate change, everything is about time and how it's time to do something about it. Are we already at a loss? What do we risk losing?

JM: We have already lost so much with mass species extinction and the glaciers that are already totally gone or in process of disappearing, and we have almost no clue what dangers lie ahead of our global chemistry experiment. Is it salvageable at this point? Yes, I think so, and we must find resilient ways of living with a damaged planet. There are things we can do to reverse this climatic trend, and there is also some hope in knowing that glaciers are never static. They always change and have changed, regardless of human impacts. I like to put people in physical contact with this immense temporal abyss.

KK: Your cyanotypes remind me of how I always think of time as being light-you know, as the earth is moving around the sun. Then I thought about the bacteria in a subglacial lake or the glacier that's melting, and these bacteria are not dealing with the sun. Time is a chemical process for them-the rocks breaking apart into small enough pieces so they can get nutrition from them. That is a chemical process that will eventually mean food for them. That's time.

JM: Yes, time can be measured and implemented in different ways. One of the reasons I like doing these cyanotypes is because of how dependent they are on the sun. The solar and the terrestrial connect during the cyanotype process. The medium implies and is dependent on this connection. I find that fascinating and part of embedding myself into place. 
KK: You had another reason, too, for staying local, right?

JM: I spent a decade backpacking and hiking around Montana with friends, and I came to really love the place. And I just didn't have the means to get to bigger glaciers, like in Greenland or Antarctica, nor did it feel necessary to participate in the carbon-heavy journey to get there. But in Montana, in a few hours I can be at a trailhead and walking to a glacier. I chose to do it in this local area of Montana where I was living, so I could build a relationship with these places. I didn't want a project where I could only go somewhere once. I wanted to create a lifelong relationship and get to know the glaciers seasonally and over the years, to go through my own life changes from getting older, growing, developing in various ways and having that personal process unfold in dialogue with these glaciers. I think that's why I started asking who was drawing whom.

Drawing felt like giving attention, so I wanted to give attention and pay respect to these places.

For me, the ethical thing to do was not just to run in and take a picture or a drawing and never go back or think of it again-ultimately, monopolizing the glacier for my own artistic benefit. Instead, I wanted to make a long-term relationship with the land. People often ask me if I'll be finished once I've drawn all the glaciers. The answer is no; I want to keep going and drawing glaciers until I'm no longer able.

Jonathan Marquis is a multimedia artist, writer, and mountaineer, seeking immersive experiences within mountainous terrain to consider posthuman geographies. His investigations of the landscape began when he launched the Glacier Drawing Project in 2014-an endeavor to draw all the remaining glaciers in the state of Montana. He has since covered thousands of miles on foot in remote mountain ranges, translating his encounters through drawing, painting, cameraless photography, and video. Marquis received his master of fine arts and art history degrees from the University of Arizona and has exhibited works across the United States and abroad, including at the Museum of Contemporary Art, Tucson; the University of Arizona Museum of Art; Missoula Art Museum, in Missoula, Montana; Center for Visual Arts, in Denver, Colorado; the University of Colorado-Pueblo; and Fine Art Complex 1101 in Tempe, Arizona. He currently splits his time between Missoula and Tucson. For more information, visit www.jonathanmarquis.com or, on Instagram, @jonathanbmarquis. 